\title{
What drives m-learning? An empirical investigation based on perceptions of university students in Pakistan
}

\author{
Shakeel Iqbal \\ Department of Management Sciences, Iqra University Islamabad Campus, Islamabad, Pakistan \\ Zeeshan Ahmed Bhattib \\ Department of Management Information Systems, Faculty of Economics and Administration, \\ King Abdul Aziz University, Jeddah, Saudi Arabia
}

\begin{abstract}
Mobile learning is gaining popularity in formal and informal education in both developed and developing countries. It can be an effective tool to overcome digital divide especially in developing countries. The success of mobile learning at tertiary level depends on the perception of students towards this contemporary medium. There is a shortage of research on m-learning in Pakistan, specifically studies showing current status of m-learning and students' perceptions towards this new mode of learning at the university level. A scientific approach (hypotheticodeductive method) was used in this study to explore the critical factors responsible for mlearning adoption among university students in Pakistan. The findings of this study, based on 628 valid survey responses, have both theoretical and practical implications for the researchers and the policy makers.
\end{abstract}

Keywords: m-learning adoption, TAM, developing countries, adoption factors.

\section{Introduction}

Mobile learning (or m-learning) can be defined as learning through mobile devices (such as mobile/Smartphones, iPods, MP3 players, personal digital assistant (PDAs)) which is delivered 
using mobile technology. M-learning is gaining popularity in both developed as well as developing countries. According to Gutierrez (2013) the top five adopters of m-learning in 2010 were U.S., Canada, South Korea, Japan and Taiwan constituting 70\% of the m-learning market; however, the share of these top five adopters was predicted to decrease to $40 \%$ by 2015 mainly due to m-learning gaining popularity in the developing world (especially in Brazil, India, China and Indonesia). Rapid adoption of mobile technology, including handheld devices and wireless networks, in university environment is making higher education an ideal candidate for integrating student-centered m-learning (Cheon, Lee, Crooks, \& Song, 2012).

Many universities around the globe are reformulating and diversifying modes of delivery and content of course offerings and the word "flexibility" and term "flexible learning" seem to be used increasingly in relation to the kinds of reformulations of course offerings that are taking place (Nicoll, 1998). M-learning is a contemporary form of flexible learning that can complement and further enhance the current learning models (Motiwalla, 2007). Moreover, it has the potential to become most effective medium of delivering learning material in higher education (El-Hussein \& Cronje, 2010).

M-learning success in educational context depends on the perceptions and participation of the stakeholders which include students, faculty, university management and support staff (Jafari, McGee \& Carmean, 2006). Students represent the user side whereas faculty and universities represents the supply side of m-learning (AUTHOR, 2012). Any m-learning initiative cannot be successful unless it is welcomed by the users i.e., students. It is, therefore, important to determine the factor affecting students' intentions to adopt m-learning especially in context of developing countries where m-learning is at a basic level. Ellis, Ginns \& Piggott (2009) indicated that without fundamental understandings of key aspects of electronic learning quality of the 
student learning is likely to be put at risk, therefore there is a need for more evidence-based research to figure out the ways we think about creating and designing online experiences to enhance the quality of learning.

\section{Theoretical Framework}

Technology acceptance theories explain the intentions as well as acceptance of a technology among users. Fishbein \& Ajzen (1975) proposed Theory of Reasoned Action (TRA), a fundamental and prominent theory related to human behavior (Venkatesh et al., 2003). According to TRA, attitude of a person and subjective norms predominantly determine his/her behavioral intention (BI) to use. There are many researchers who reported a significant correlation between actions and behavioral intention (e.g., Sheppard, Harwick \& Warshaw, 1988). TRA is originally a general model and, hence, not suitable for explaining the behavior in specific circumstances (Davis et al., 1989). Theory of Planned Behavior (TPB) is an extension of TRA in which Ajzen (1991) added a new construct: Perceived behavioral control (PBC): a person's perception that he or she can perform a certain behavior with ease. TPB has rarely been used in IS/IT research, hence it has the limitations of non-availability of proper scale and empirical base (Leong, 2003). The TPB is open to further expansion as pointed out by Ajzen (1991).

Technology Acceptance Model (TAM) was developed by Davis (1989) as an extension of TRA to explain and predict the acceptance of IS. The two main constructs used in TAM are PU and PEU. PU is defined as "the degree to which a person believes that using a particular system would enhance his or her job performance" whereas PEU is defined as "the judgment with respect to amount of effort required to use a system" (Davis, 1989, p. 320). PU and PEU affect a 
users' attitude towards using a system, which affects behavioral intention (BI) to use and actual use of the system. Davis (1989) suggested that the predictive capability of TAM with respect to future adoption of a new technology could be enhanced by incorporating external variables in it. TAM is preferred over TRA and TPB because of its widespread popularity. The main advantages claimed for TAM as pointed out by Mathieson (1991) are: TAM is parsimonious, IT specific, the scales used for measurement are well-researched and validated and availability of strong empirical support. TAM's inability to explicitly state the external factors is viewed as one of the weaknesses of TAM. External factors affecting acceptance of a new technology vary from situation to situation depending upon the situation, users and technology characteristics (Moon \& Kim, 2001). Venkatesh \& Davis (2000) introduced TAM2 which included several determinants of PU.

\section{Empirical Studies on M-Learning adoption}

Pollara \& Broussard (2011) conducted a review of 18 studies, published during 2005-2010, focusing on students perceptions of m-learning. 17 out of 18 studies reviewed reported a positive attitude of students towards m-learning. There are several studies conducted on the topic of mlearning adoption among university students using TAM, some of which are mentioned in table 1:

Table 1: TAM based M-learning studies

\begin{tabular}{cccc}
\hline Authors & IS & Samples & Results \\
& Application & & \\
\hline \hline Huang, Lin \& & M-learning & 313 university & Individual differences are important to \\
Chuang (2007) & & students & define user acceptance whereas
\end{tabular}


enjoyment can predict users' intention of using m-learning

\begin{tabular}{|c|c|c|c|}
\hline Liu, Li \& & M-learning & 230 & Perceived near-term and long-term \\
\hline Carlsson & & undergraduate & usefulness and personal innovativeness \\
\hline$(2010)^{*}$ & & students & have significant influence on m-learning \\
\hline & & & adoption intention, while perceived \\
\hline & & & long-term usefulness \\
\hline & & & the perceived \\
\hline & & & usefulness. \\
\hline
\end{tabular}

$\begin{array}{llll}\text { Chang, Yan \& } & \text { M-learning } & 158 \text { college } \quad \text { PU and PEU and perceived convenience }\end{array}$
Tseng (2012)* students are important factors for acceptance of English mobile learning as well as these factors have significant effect on attitude towards use.

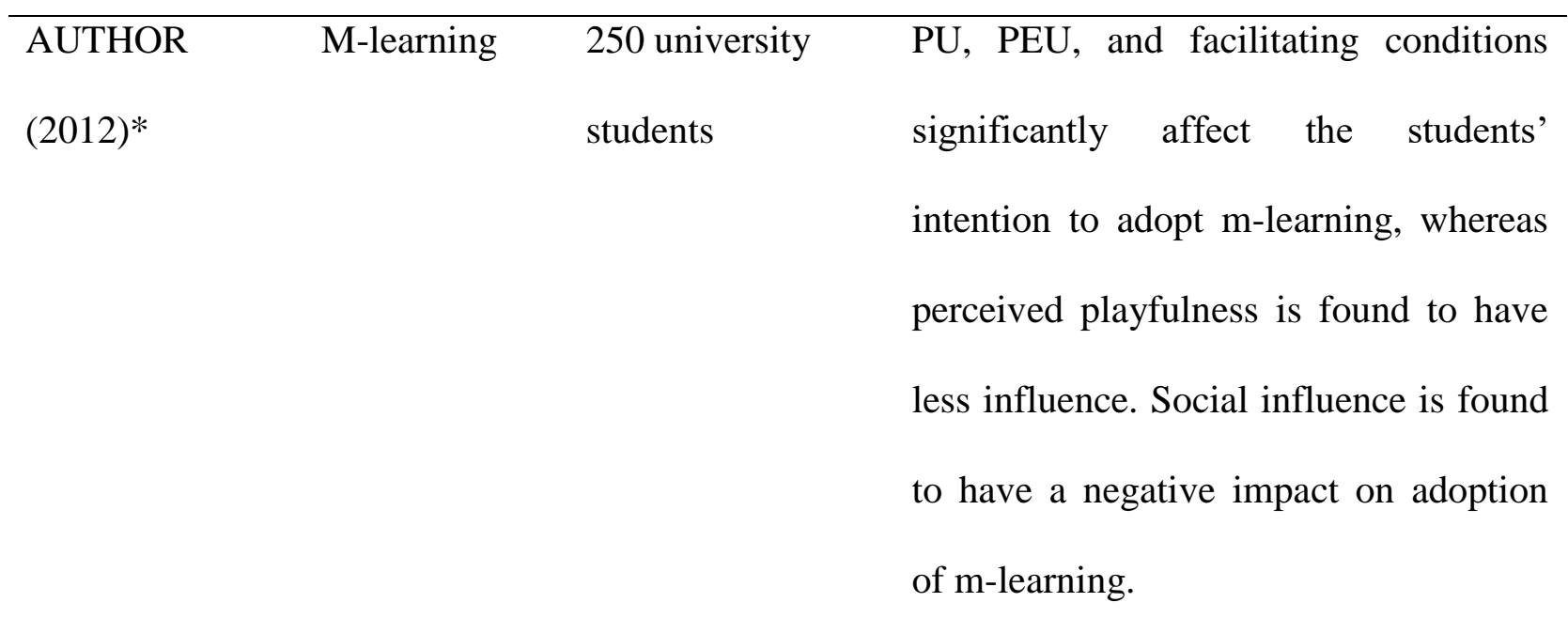

[Source: Liu, Han, Li (2010). *References marked with (*) added by researcher]. 
A limited research on the topic of m-learning adoption and its determinants is conducted in developing countries' context especially in Pakistan.

\section{Constructs and associated hypotheses}

Koole (2009) proposed a FRAME (Framework for the Rational Analysis of Mobile Education) model which defines m-learning as a process based on the interaction among learners, mobile technology and societal factors and the same three factors are used in the conceptual model as external variables affecting TAM.

\section{Learner Related Factors}

The learners' related factors considered for this study, based on the literature review, include students' readiness and self-management of learning and are discussed below:

\section{Student Readiness (SR)}

Readiness to use technology can be defined as the tendency to accept and use a new technology to carry out tasks related to work or home. According to Pillay, Irving \& Tones (2007) computer self-efficacy, technical skills, attitude towards computers and learning preferences are main the qualities that may explain individual differences in academic achievement and satisfaction in online learning environments. Social Cognitive Theory suggests that performing a specific skill positively influence self-efficacy perception and PEU of TAM is a measure of self-efficacy (Davis, 1989). An innovative person might find a new system useful (PU) and easy to use rapidly as compared to a non-innovative person (Schillewaert et al., 2005). The above discussion leads us to formulate the following hypotheses:

H1: SR has a significant impact on PU of m-learning.

H2: SR has a significant impact on PEU of m-learning.

\section{Self-Management of Learning (SML)}


The concept of SML should be considered as one of the vital concept for probing the acceptance of mobile learning as suggested by Chen et al. (2002) and Huang et al. (2011). The students exhibiting self-management skills have demonstrated better results in online learning setup as pointed out by Chen et al. (2002). Moreover, it is also reported in previous research that individuals with superior self-discipline skills can adopt m-learning much quickly than others (Wang, Wu \& Wang, 2009). This discussion leads us to frame the following hypotheses:

H3: SML has a significant impact on PU of m-learning.

H4: SML has a significant impact on PEU of m-learning.

\section{Technology Specific Factors}

The two commonly used m-learning specific adoption factors indicated in literature are mobility and perceived playfulness which are discussed below:

\section{Mobility (MOB)}

The distinctive characteristic of mobile technology is its mobility: anywhere/anytime access to information through wireless networks and mobile devices. Independence of time and place is the core of mobility and is very close to the concept of "anytime and anywhere" computing introduced by Kleinrock (1996). Different researchers have investigated the relationship between perceived mobility and PU and PEU. Kim, Mirusmonov \& Lee (2010) reported a positive effect of mobility on PU in their study related to mobile payments, while Schierz, Shilke \& Wirtz (2010) did not found this relationship positive in mobile payment service context. Kim et al. (2010) also studied the impact of mobility on PEU and reported the impact to be insignificant. Based on the foregoing we hypothesize:

H5: MOB has a significant impact on PU of m-learning.

H6: MOB has a significant impact on PEU of m-learning. 


\section{Perceived Playfulness (PP)}

A learner's playfulness, referred to as his or her "cognitive spontaneity and sense of pleasure in undertaking a task" (Spence \& Usher, 2007, p. 269), can be considered a crucial element to affect learning engagement particularly with reference to innovation in teaching. There are several studies which indicate a positive correlation among perceived playfulness and users' intention e.g., Moon \& Kim (2001) who extended the TAM to include PP as an intrinsic motivation factor. Intrinsic motivators lead to increased interaction because of the user's interest in the activity. PP possibly can influence the users' behavior and hence, is included in the research model.

H7: PP has a significant impact on PU of m-learning.

H8: PP has a significant impact on PEU of m-learning.

\section{External Drivers of m-learning adoption}

The three potential external drivers of m-learning adoption pointed out by the researchers in their studies conducted on the topic of m-learning adoption are social influence, faculty support and university support which are discussed below:

\section{Social Influence (SI)}

Social influence (SI) is defined as "the degree to which an individual perceives that important others believe he or she should use the new system" (Venkatesh et al., 2003, p.451). SI is included as a factor affecting BI in other acceptance models as well such as TAM and TPB. Previous studies suggest that SI significantly affect BI towards the use of a new technology (Venkatesh \& Davis, 2000). In case of m-learning, SI can be in the form of peer pressure or influence of instructor (Miller et al., 2003). Social influence could encourage people to adopt a new technology by indirectly influencing their attitude via PU and PEU and hence, we propose: H9: SI has a significant impact on PU of m-learning. 
H10: SI has a significant impact on PEU of m-learning.

\section{Faculty Support (FS)}

The role of teachers had been changing with change in technology. According to Ozdamli and Cavus (2011) the teacher's role in an m-learning environment is to motivate the learners, facilitate and guide them, to arrange activities that promote interactive learning between collaborative groups and organize activities for assessment of learners. A person might consider a system useful and form an intention to use it if his superior (due to his position) suggests about the usefulness of that particular system (Miller et al., 2003). Jung et al. (2002) studied the behavior of students enrolled in an online course and found that the teacher's presence had a strong effect on students' perception towards ease of using online system (PEU), their motivation, course engagement and achievement. The following hypotheses related to FS are formulated:

H11: FS has a significant impact on PU of m-learning.

H12: FS has a significant impact on PEU of m-learning.

\section{University Support (US)}

The university support in term of financing, training, technical support and commitment from senior management is crucial for seamless integration of technology in learning. It is pointed out in several studies that individual adoption of any technology is not only dependent on personal beliefs and perception but also on management actions, strategies and policies (Leonard-Barton \& Deschamps, 1988). Adequate support services could affect both PU and PEU (Lee, Kozar \& Larsen, 2001). Venkatesh (2000) concluded that facilitating conditions influenced PU and PEU positively. Hart \& Henriques (2006) reported that top management support positively affected PEU, but its effect on PU was found negative. Hence the following hypotheses are formulated: 
H13: US has a significant impact on PU of m-learning.

H14: US has a significant impact on PEU of m-learning.

\section{Adoption Factors defined in TAM}

\section{Perceived Usefulness (PU) \& Perceived Ease of Use (PEU)}

Both PU and PEU are reported to have a considerable impact on behavioral intention to use a new technology (e.g. see Chau, 1996). Hence it is hypothesized that:

H15: PU has a significant impact on BI to use m-learning.

H16: PEU has a significant impact on BI to use m-learning.

According to TAM, both PU and PEU are strongly correlated. It means, if all other factors are held constant, individual's perception regarding usefulness of a technology will highly depend on ease of use of that technology (Igbaria et al., 1995) therefore it is hypothesized that:

H17: PEU has a positive effect on PU of m-learning.

\section{Behavioral Intention (BI)}

Fishbein and Ajzen (1975) defined BI as "a measure of the strength of one's intention to perform a specified behavior" (p. 288). BI in this study is used to indicate the inclination of an individual towards adoption of m-learning technology. Previous researches support the idea both PU and PEU had significant impact on a user's BI (O'Cass \& Fenech, 2003).

\section{Actual Usage (AU) of m-learning}

In TAM, actual usage of a specific technology is defined to be dependent upon the BI of a user towards that technology (Davis et al., 1989). In practice, it is difficult to predict that a specific behavior towards a new technology will also lead to its actual usage. However, positive correlation between BI and actual usage of technology is reported in several studies (e.g., Vijayasarathy, 2004). Similarly, it is hypothesized: 
H18: BI has a significant impact on actual use (AU) of m-learning.

The research model derived from the literature review discussed in this chapter is presented in Figure 1:

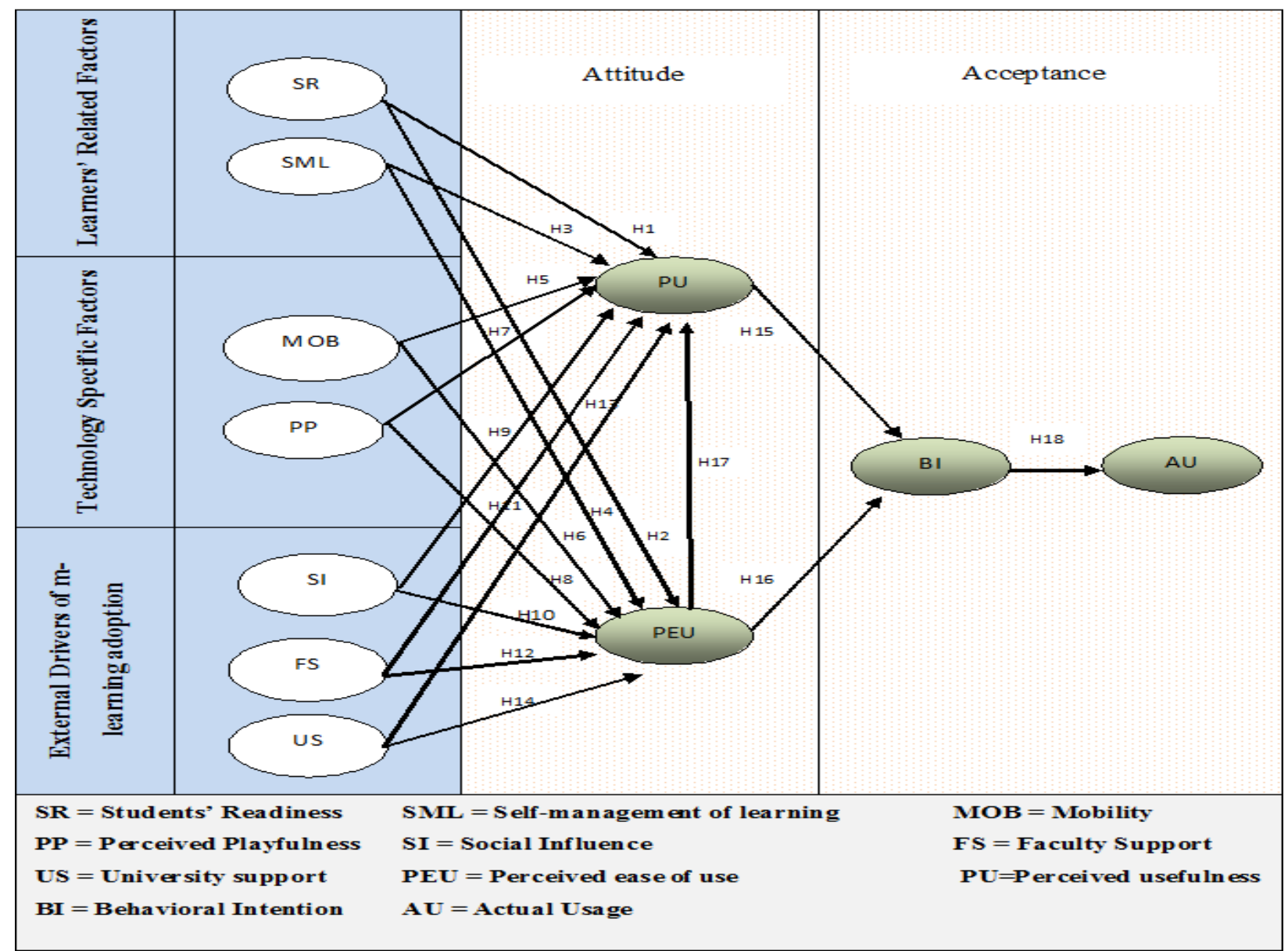

Figure 1: Conceptual Model of the research

\section{Methodology}

\section{Population/Sample/Sampling}

The current study follows a hypothetico-deductive approach. University students belonging to different public and private sector universities of Pakistan are the target population. A mixed methods (MM) sampling is used in this study. In MM sampling, probability and purposive sampling techniques are combined for selection of sampling units (Teddlie \& Yu, 2007). 
Stratified purposive sampling is one of the popular MM sampling techniques. In this technique, the entire population is divided into different strata and then few cases are selected, using purposive sampling, from each stratum. In this study the entire population of students is divided into five strata to represent the four provinces and the federal capital. Since the target is to get information from the students who are familiar with Smartphone usage, those universities were purposefully selected where the students mostly come from the upper/upper middle class and mostly own Smartphones. Sample size generally recommended for structural equation modeling is 200 or 10 cases per parameter (Kline, 2011).

\section{Instrument \& Measures}

The questionnaire was based on validated research instruments developed by different researchers who conducted research on this topic. The final instrument used in this study consisted of 11 variables as mentioned in table 2 :

Table 2: Variables used in Study, Codes and References

\begin{tabular}{|c|c|c|}
\hline Variables & Code & References \\
\hline Student Readiness & SR & $\begin{array}{l}\text { Compeau \& Higgins (1995); Schillewaert et } \\
\text { al. (2005); Hussin et al. (2012); Ismail et al. } \\
\text { (2013) }\end{array}$ \\
\hline Mobility & MOB & $\begin{array}{l}\text { Mallat et al. (2006); Huang et al. (2007); } \\
\text { Kim et al. (2010). }\end{array}$ \\
\hline Perceived Playfulness & $\mathrm{PP}$ & Moon \& Kim (2001); Wang et al. (2009) \\
\hline $\begin{array}{l}\text { Self Management of } \\
\text { Learning }\end{array}$ & SML & Huang et al. (2011) \\
\hline Social Influence & SI & Venkatesh et al. (2003); Wang et al. (2009) \\
\hline Faculty Support & FS & $\begin{array}{l}\text { Schillewaert et al. (2005); Igbaria et al. } \\
\text { (1995); Leonard-Barton \& Deschamps } \\
\text { (1988) }\end{array}$ \\
\hline University Support & US & $\begin{array}{l}\text { Igbaria, Pavri \& Huff (1989); Igbaria et al. } \\
\text { (1995); Schillewaert et al. (2005) }\end{array}$ \\
\hline Perceived Usefulness & PU & $\begin{array}{l}\text { Davis (1989, 1993); Venkatesh and Davis } \\
\text { (1996); Moon \& Kim (2001) }\end{array}$ \\
\hline
\end{tabular}


Perceived Ease of Use

Behavioral Intention

Actual Use
PEU Davis (1989, 1993); Venkatesh and Davis (1996); Moon \& Kim (2001)

BI Hu et al. (1999); Moon \& Kim (2001)

AU Compeau, Higgins, \& Huff (1999).

Pilot testing of questionnaire was conducted before final survey. Based on the respondents' feedback and expert's opinion, the questionnaire was further refined before the final survey. The final survey resulted in 628 valid responses which were further analyzed.

\section{Instrument Validity and Reliability}

The dataset was analyzed to establish the convergent and discriminant validity and reliability. Exploratory factor analysis (EFA) and confirmatory factor analysis (CFA) were conducted to confirm the convergent and discriminant validity; while the reliability of the instrument was checked means of Cronbach Alpha values. The results of principal component factor analysis (PCFA) suggested retaining all the factors proposed in conceptual model except in case of students' readiness (SR) and faculty support (FS). Students' readiness converged on three separate constructs identified as Personal Innovativeness, Skills Readiness and Psychological Readiness; whereas faculty support converged on two separate dimensions identified as Passive Faculty Support and Active Faculty Support. Sub-hypotheses for SR and FS were accordingly developed.

After exploratory analysis the reliability of the measuring scales was checked by means of Cronbach Alpha The acceptable value of Cronbach Alpha for establishing reliability is 0.6 (Nunnally, 1978); however Cronbach value for all the fourteen constructs was above 0.9 which indicated that the instrument was reliable. Based on the results of EFA and reliability analysis, fourteen variables were finalized for further analysis. The fitness of research model was analyzed using CFA. Fornell \& Larcker's (1981) suggested method was used to assess the discriminant 
validity of the constructs used in the proposed model. The square roots of the average variance extracted (AVE) for these constructs were compared with their corresponding correlation values as shown in Table 3.

Table 3: Correlation Matrix and Discriminant Analysis

\begin{tabular}{lcccccccccc}
\hline & PI & SKR & PSR & MOB & PP & SML & SI & PFS & AFS & US \\
\hline \hline PI & $\mathbf{0 . 9 1}$ & & & & & & & & & \\
SKR & $.220^{* *}$ & $\mathbf{0 . 9 0 4}$ & & & & & & & & \\
PSR & $.426^{* *}$ & $.390^{* *}$ & $\mathbf{0 . 9 2 4}$ & & & & & & & \\
MOB & $.394^{* *}$ & $.275^{* *}$ & $.335^{* *}$ & $\mathbf{0 . 8 8 5}$ & & & & & & \\
PP & $.353^{* *}$ & $.348^{* *}$ & $.435^{* *}$ & $.298^{* *}$ & $\mathbf{0 . 9 4 2}$ & & & & & \\
SML & $.391^{* *}$ & $.345^{* *}$ & $.368^{* *}$ & $.400^{* *}$ & $.372^{* *}$ & $\mathbf{0 . 9 3 4}$ & & & & \\
SI & $.288^{* *}$ & $.223^{* *}$ & $.283^{* *}$ & $.331^{* *}$ & $.295^{* *}$ & $.282^{* *}$ & $\mathbf{0 . 9 2 5}$ & & & \\
PFS & $.383^{* *}$ & $.379^{* *}$ & $.465^{* *}$ & $.315^{* *}$ & $.492^{* *}$ & $.386^{* *}$ & $.324^{* *}$ & $\mathbf{0 . 9 2 4}$ & & \\
AFS & $.423^{* *}$ & $.295^{* *}$ & $.476^{* *}$ & $.386^{* *}$ & $.373^{* *}$ & $.429^{* *}$ & $.355^{* *}$ & $.474^{* *}$ & $\mathbf{0 . 9 3 5}$ & \\
US & $.342^{* *}$ & $.290^{* *}$ & $.333^{* *}$ & $.213^{* *}$ & $.426^{* *}$ & $.250^{* *}$ & $.376^{* *}$ & $.455^{* *}$ & $.377^{* *}$ & $\mathbf{0 . 9 3 1}$ \\
\hline **. Correlation is significant at the 0.01 level (2-tailed). & & & & &
\end{tabular}

The diagonal values in the above table represent the square roots of AVE for each of the ten constructs defined as external variables affecting TAM. As it can be seen that the diagonal values are higher compared to the values in the corresponding rows and columns, the discriminant validity of these constructs used in the proposed model is confirmed.

\section{Results of Hypotheses Testing}

The proposed model for this study was tested using AMOS. The standardized weights for the model are shown in Figure 2. 


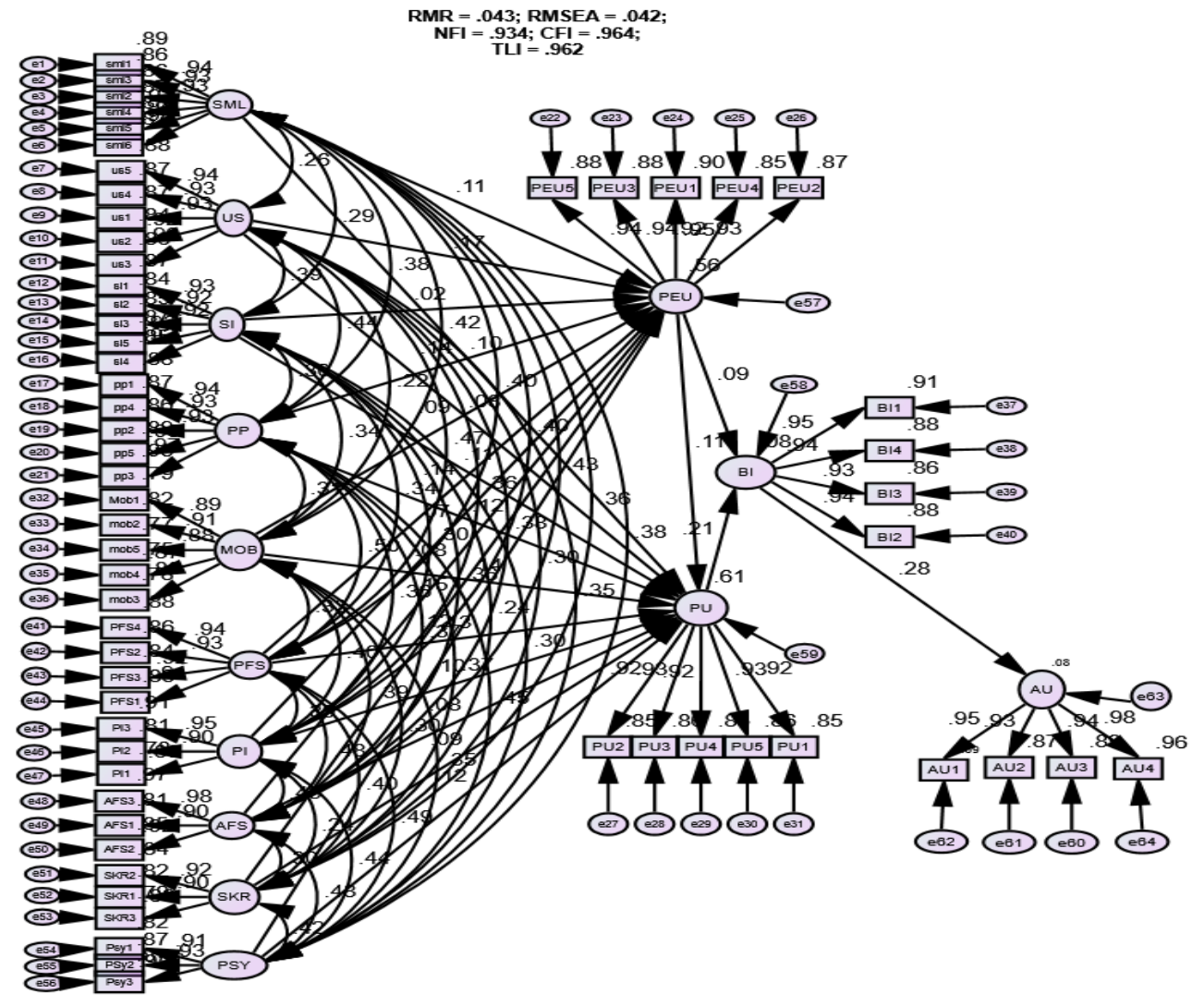

Figure 2: SEM Path Analysis Results

The goodness of fit indices are mainly divided into three categories: parsimony fit indices, absolute fit indices and incremental fit indices (e.g. see Hooper, Coughlan \& Mullen, 2008). The measurement model meets these three criteria recommended by the experts for estimating the fitness of the model as shown in Table 4. 
Table 4: Results for CFA - Measurement model

\section{Model Fit Indices}

\begin{tabular}{|c|c|c|c|c|}
\hline Type & Indices & Recommended & Observed & $\begin{array}{c}\text { Reference for recommended } \\
\text { values }\end{array}$ \\
\hline $\begin{array}{l}\text { Parsimony Fit } \\
\text { Index }\end{array}$ & CMIN/df & $<3$ & 2.097 & (Kline, 2011) \\
\hline $\begin{array}{l}\text { Absolute Fit } \\
\text { Indices }\end{array}$ & $\begin{array}{c}\text { RMR } \\
\text { RMSEA }\end{array}$ & $\begin{array}{c}<0.05 \\
<0.05-<0.08\end{array}$ & $\begin{array}{l}0.043 \\
0.042\end{array}$ & $\begin{array}{l}\text { (Hu \& Bentler, 1999; Kline, } \\
\text { 2011) } \\
<.06 \text { (Hu and Bentler, 1999); } \\
<0.07 \text { (Steiger, 2007) }\end{array}$ \\
\hline $\begin{array}{l}\text { Incremental Fit } \\
\text { Indices }\end{array}$ & $\begin{array}{l}\text { NFI } \\
\text { CFI } \\
\text { TLI }\end{array}$ & $\begin{array}{l}>0.900 \\
>0.900 \\
>0.900\end{array}$ & $\begin{array}{l}0.934 \\
0.964 \\
0.962\end{array}$ & $\begin{array}{l}\text { (Bentler and Bonnet, 1980) } \\
\text { (Hu and Bentler, 1999) } \\
\text { (Hu \& Bentler, 1999; Kline, } \\
\text { 2011) }\end{array}$ \\
\hline
\end{tabular}

Based on the path coefficients and t-values the results of hypotheses testing are presented in Table 5:

Table 5: Hypotheses testing results

\begin{tabular}{|c|c|c|c|c|}
\hline Hypotheses & Path & Path coefficient & t-value & Results \\
\hline H1a & PI -> PU & 0.095 & $2 . .813$ & Accepted \\
\hline $\mathrm{H} 1 \mathrm{~b}$ & SKR -> PU & 0.092 & 2.798 & Accepted \\
\hline $\mathrm{H} 1 \mathrm{c}$ & PSR -> PU & 0.117 & 3238 & Accepted \\
\hline $\mathrm{H} 2 \mathrm{a}$ & $\mathrm{PI}->\mathrm{PEU}$ & 0.072 & 2.010 & Accepted \\
\hline $\mathrm{H} 2 \mathrm{~b}$ & SKR -> PEU & 0.150 & 4.379 & Accepted \\
\hline $\mathrm{H} 2 \mathrm{c}$ & PSR -> PEU & 0.124 & 3.281 & Accepted \\
\hline $\mathrm{H} 3$ & MOB -> PU & 0.144 & 4.381 & Accepted \\
\hline $\mathrm{H} 4$ & MOB -> PEU & 0.094 & 2.726 & Accepted \\
\hline H5 & PP -> PU & 0.119 & 3.488 & Accepted \\
\hline H6 & PP -> PEU & 0.144 & 4.026 & Accepted \\
\hline $\mathrm{H} 7$ & SML $->P U$ & 0.099 & 2.993 & Accepted \\
\hline H8 & SML -> PEU & 0.112 & 3.222 & Accepted \\
\hline $\mathrm{H} 9$ & $\mathrm{SI}->\mathrm{PU}$ & 0.108 & 3.485 & Accepted \\
\hline H10 & SI -> PEU & 0.025 & 0.756 & Rejected \\
\hline $\mathrm{H} 11 \mathrm{a}$ & PFS -> PU & 0.125 & 3.394 & Accepted \\
\hline $\mathrm{H} 11 \mathrm{~b}$ & PFS -> PEU & 0.141 & 3667 & Accepted \\
\hline $\mathrm{H} 12 \mathrm{a}$ & AFS -> PU & 0.078 & 2.271 & Accepted \\
\hline $\mathrm{H} 12 \mathrm{~b}$ & AFS -> PEU & 0.082 & 0.024 & Accepted \\
\hline H13 & US -> PU & 0.079 & 2.348 & Accepted \\
\hline
\end{tabular}




\begin{tabular}{lllll} 
H14 & US -> PEU & 0.172 & 4.968 & Accepted \\
H15 & PEU -> PU & 0.112 & 2.743 & Accepted \\
H16 & PU -> BI & 0.214 & 4.113 & Accepted \\
H17 & PEU -> BI & 0.089 & 1.723 & Accepted \\
H18 & BI -> AU & 0.276 & 6.933 & Accepted \\
\hline
\end{tabular}

As shown in Table 8 all the proposed hypotheses except one are accepted; the affect of social influence $(\mathrm{SI})$ on perceived ease of use PEU (coefficient $=.025$, t-value $=0.756, \mathrm{p}$-value $=0.449$ ) is not found significant and hence the related hypothesis (10) is rejected.

\section{Discussion of the results}

The results of this study indicated personal innovativeness (PI) of students has significant impact on both PU and PEU. Those individuals who posses high degree of innovativeness are ready for adopting a change since they are in a better position to make constructive use of information specific to an innovation (Leavitt and Walton, 1975). PI is reported as a significant predictor of PEU in the studies of Liu et al. (2010) and Tan, Ooi, Leong \& Lin (2014). PI is reported to have a significant impact on long-term PU in a study conducted by Liu et al. (2010). Skills readiness (SKR) in context of m-learning refers to existing knowledge about an innovation which is a central psychological determinant of consumer behavior (Bauer et al., 2005). The fact that an individual possesses certain knowledge and skill to use a new technology will negatively affect his perception towards that innovation's complexity. The innovation of diffusion theory suggests a negative correlation between acceptance of a new technology and its perceived complexity (Rogers, 1983). Psychological readiness (PSR) indicates a positive state of mind towards the use and usefulness of a new technological which will increase the chances of its adoption. Self management of learning (SML) has significant impact on students' PEU and PU. The results support the view that learners with highly autonomous learning ability are most suitable for this 
form of learning compared to learners with less autonomous learning capability (Wang et al., 2009).

Mobility (MOB) has significant positive impact on PU and PEU. MOB significantly affects PEU which is consistent with findings of Jarvenpaa and Lang (2005). Mallat et al. (2006) asserted that the concept of MOB is closely related to the performance gain offered by mobile technology; hence it is associated with the concept of PU. The results of the study indicate that perceived playfulness (PP) has significant impact on both PU and PEU. Flow theory (Csikszentmihalyi, 1990) suggests that positive subjective experience is an important factor causing an activity. An activity that results in "feeling good" state is the one which can be categorized as intrinsically motivating and people are more likely expected to engage in it (Teo \& Noyes, 2011). A significant positive affect of perceived enjoyment on PEU is reported in the studies of Venkatesh (2000) and Teo \& Noyes (2011). The present day universities are increasingly occupied by Generation Y (those born during1980-2000) and it is argued the Generation Y student displays radically new learning styles which can only be engaged in the classroom through new teaching strategies and learning spaces (Sternberg, 2012).

Social Influence (SI) does not have a significant impact on PEU as hypothesized. A similar finding was reported in a study by Shen et al. (2006) in which peer influence on technology adoption was not found significant. The possible reason could be the technical limitations such as small screen size, miniature key pad, short battery life and less computational power (Siau et al., 2001) which make these devices less ideal for educational use. These limitations of mobile devices generally add to the anxiety of a learner and negatively affect his feeling of convenience. However, SI is found to have significant impact on PU. This finding suggest that when a large 
number of people are using a certain technology the non-users might start thinking that this technology is useful as it is being used by many people.

In educational settings, the learner's motivation is generally affected by the faculty. Faculty support in case of technology adoption can be in terms of persuasion to adopt a new technology (referred here as passive faculty support: PFS) and/or it can be practically helping learners to adopt a new technology (referred as active faculty support: AFS). The results indicate that faculty persuasion (PFS) has significant positive impact on PEU and PU of m-learning. The students' level of anxiety towards a new technology is lowered once they have the confidence that their teacher is available to help them out. The teachers can be instrumental in convincing students that a new technology will lead to their increased productivity, thus positively affecting their PU. University support positively influence students' PEU and PU and this finding is supported by other studies which confirm that successful adoption of m-learning depends on technical support, staff training and offering mobile compatible learning material (Barker, Krull, \& Mallinson, 2005).

A strong positive impact of PU on m-learning is found on students' behavioral intention (BI) to adopt m-learning similar to the studies of Liu et al., (2010); Cheon et al., (2012); Tan et al., (2014). Liu et al (2010) suggests that a key factor influencing the students' intention to adopt mlearning is the meaningful use of mobile devices in course related activities. Perceived ease of use (PEU) is found to have a significant positive impact on behavioral intention to use $\mathrm{m}$ learning as reported by Chung, Chen, \& Kuo (2015). This finding suggests that students are interested in m-learning because of its convenience features: easy to carry and all in one approach used in mobile devices. However, PEU is generally found to be a relatively weak predictor of BI compared to PU as pointed out by Keil et al. (1995) "no amount of PEOU will 
compensate for low usefulness" [p.89]. Similar to many TAM related studies a significant positive impact of PEU is found on PU (e.g. see Kim et al., 2010; Huang et al., 2007, Tan et al., 2014). Generally speaking an innovation that is easier to use and enhances productivity is more likely to be adopted by masses.

The results of the study show that students' actual behavior is significantly affected by their behavioral intention. In literature mixed findings are reported for the relationship between BI and AU. A positive relationship is reported between these two variables in several previous studies (e.g., see Davis et al., 2002; Martins, Oliveira, \& Popovič, 2014).

\section{Conclusion}

The results of structural equation modeling confirmed significant positive impact of all the student related and technology specific factors on PEU and PU. Out of the three external factors affecting TAM, two factors i.e., faculty and university support significantly affect PU and PEU. However, SI significantly affects PU but not PEU. PU is found a strong predictor of students' BI to use m-learning as compared to PU. A direct impact of $\mathrm{BI}$ on actual use of m-learning is reported in this study.

\section{Contributions of this study}

This study addresses the weakness of TAM by incorporating external variables specific to mlearning environment. A comprehensive m-learning adoption model is proposed in which adoption factors are divided into three categories: Users' specific factors, technology specific factors and external driving factors (in terms of support and influence). Another contribution of this study is explanation (operationalization) of students' readiness in terms of m-learning adoption. It is reported that students' readiness for m-learning encompasses their personal innovativeness, skills readiness and psychological readiness. This study extends the 
understanding of the concept of faculty support in m-learning adoption by defining it in terms of passive faculty support and active faculty support. Moreover, it adds to limited literature available on m-learning adoption in developing countries' context.

\section{Practical Implications}

The findings of this study are helpful for policy makers, university administration, application developers and device manufacturers. For successful adoption of m-learning at the university level, the university management should focus on enhancing the students' readiness specifically skills readiness and psychological readiness. Different training courses and workshops can be conducted for this purpose. Different courses should be introduced to enhance the self management skills of the students as the findings of this study suggest that those students who demonstrate higher degree of self-management skills are in a better position to adopt m-learning. Mobility is identified as a key advantage of m-learning which suggests that university management and policy makers should introduce m-learning programs focusing the portable mobile devices (such as PDAs and Smartphones). Perceived playfulness is also found a crucial predictor of m-learning adoption, hence game-based, media enriched and interactive m-learning applications should be developed by application developers to make learning fun. Faculty support is an important factor for successful adoption of m-learning; therefore the university management should focus on teachers training to help them incorporate mobile technology in their teaching. University support in terms of financing, providing required hardware and software, technical support, content development and training of faculty and students is important for successful m-learning adoption. 


\section{Limitations of the Study}

The limitations of this study include: Firstly, a limited sample, students belonging to six selected universities from the large developed cities, was considered in this study. Secondly this study has been conducted from a developing country's perspective where m-learning is at a very basic level. Third limitation of this study is its research design (i.e. cross sectional analysis) which could result in common method bias. Lastly, the study is carried out in higher education context and hence, the same results might not be obtained for any research conducted in commercial/corporate setting.

\section{Future Directions}

The study is conducted in one country, cross country studies are recommended to further validate the results of this study. To overcome the issue of common method bias it is recommended to conduct a longitudinal study on this topic. It is also recommended to test this model in corporate settings such as service industry or financial industry to see if similar results are obtained or not.

\section{References}

Agudo-Peregrina, Á., Hernández-García, Á., \& Pascual-Miguel, F. (2014). Behavioral intention, use behavior and the acceptance of electronic learning systems: Differences between higher education and lifelong learning. Computers in Human Behavior, 34, 301-314. doi:10.1016/j.chb.2013.10.035

Ajzen, I. (1991). The theory of planned behavior, Organizational Behavior and Human Decision Processes, 50 (2), 179-211.

Barker, A., Krull, G., \& Mallinson, B. (2005, October). A proposed theoretical model for mlearning adoption in developing countries. In Proceedings of mLearn ( 2005, p. 4th). 
Bauer, H. H., Barnes, S. J., Reichardt, T., \& Neumann, M. M. (2005). Driving consumer acceptance of mobile marketing: A theoretical framework and empirical study. Journal of Electronic Commerce Research, 6(3), 181-192.

Bentler, P., \& Bonett, D. (1980). Significance tests and goodness of fit in the analysis of covariance structures. Psychological Bulletin, 88(3), 588-606. doi:10.1037/00332909.88.3.588

Chang, C. C., Yan, C. F., \& Tseng, J. S. (2012). Perceived convenience in an extended technology acceptance model: Mobile technology and English learning for college students. Australasian Journal of Educational Technology, 28(5), 809-826.

Chau, P. Y. (1996). An empirical assessment of a modified technology acceptance model. Journal of management information systems, 185-204.

Chen, Y. S., Kao, T. C., Sheu, J. P., \& Chiang, C. Y. (2002). A mobile scaffolding-aid-based bird-watching learning system. In Wireless and Mobile Technologies in Education, 2002. Proceedings. IEEE International Workshop on (15-22). IEEE.

Cheon, J., Lee, S., Crooks, S., \& Song, J. (2012). An investigation of mobile learning readiness in higher education based on the theory of planned behavior. Computers \& Education, 59(3), 1054-1064. doi:10.1016/j.compedu.2012.04.015

Chung, H., Chen, S., \& Kuo, M. (2015). A Study of EFL College Students' Acceptance of Mobile Learning. Procedia - Social and Behavioral Sciences, 176, 333-339. doi:10.1016/j.sbspro.2015.01.479

Compeau, D., \& Higgins, C. (1995). Computer Self-Efficacy: Development of a Measure and Initial Test. MIS Quarterly, 19(2), 189. doi:10.2307/249688 
Compeau, D., Higgins, C., \& Huff, S. (1999). Social Cognitive Theory and Individual Reactions to Computing Technology: A Longitudinal Study. MIS Quarterly, 23(2), 145. doi: $10.2307 / 249749$

Csikszentmihalyi, M. (1990). Flow: The psychology of optimal experience. New York: HarperPerennial.

Davis, F. (1989). Perceived Usefulness, Perceived Ease of Use, and User Acceptance of Information Technology. MIS Quarterly, 13(3), 319. doi:10.2307/249008

Davis, F. (1993). User acceptance of information technology: system characteristics, user perceptions and behavioral impacts. International Journal of Man-Machine Studies, 38(3), 475-487. doi:10.1006/imms.1993.1022

Davis, F., Bagozzi, R., \& Warshaw, P. (1989). User Acceptance of Computer Technology: A Comparison of Two Theoretical Models. Management Science, 35(8), 982-1003. doi: $10.1287 / \mathrm{mnsc} .35 .8 .982$

Davis, L., Ajzen, I., Saunders, J., \& Williams, T. (2002). The decision of African American students to complete high school: An application of the theory of planned behavior. , 94(4), 810-819. doi:10.1037//0022-0663.94.4.810

El-Hussein, M. O. M., \& Cronje, J. C. (2010). Defining mobile learning in the higher education landscape. Educational Technology \& Society, 13(3), 12-21.

Ellis, R. A., Ginns, P., \& Piggott, L. (2009). E-learning in higher education: some key aspects and their relationship to approaches to study. Higher Education Research \& Development, 28(3), 303-318. 
Fishbein, M., Ajzen, I. (1975). Belief, Attitude, Intention and Behavior: An Introduction to Theory and Research, Addison-Wesley, Reading, MA.

Fornell, C., \& Larcker, D. (1981). Evaluating Structural Equation Models with Unobservable Variables and Measurement Error. Journal of Marketing Research, 18(1), 39. doi:10.2307/3151312

Gutierrez, K. (2013). 20 Eye-Opening Stats You Probably Didn’t Know About Mobile Learning. Retrieved April 2014, from http://info.shiftelearning.com/blog/bid/271043/20-EyeOpening-Stats-You-Probably-Didn-t-Know-About-Mobile-Learning

Hart, M., \& Henriques, V. (2006). On the influence of facilitating conditions on DSS usage. Preface of the Editors, 135.

Hooper, D., Coughlan, J. \& Mullen, M. R. (2008). Structural Equation Modelling: Guidelines for Determining Model Fit. The Electronic Journal of Business Research Methods, 6 (1), 53 $-60$.

Hu, L., \& Bentler, P. (1999). Cutoff criteria for fit indexes in covariance structure analysis: Conventional criteria versus new alternatives. Structural Equation Modeling: A Multidisciplinary Journal, 6(1), 1-55. doi:10.1080/10705519909540118

Huang, J. H., Lin, Y. R., \& Chuang, S. T. (2007). Elucidating user behavior of mobile learning: A perspective of the extended technology acceptance model. Electronic Library, The, 25(5), 585-598.

Huang, R., Jang, S., Machtmes, K., \& Deggs, D. (2011). Investigating the roles of perceived playfulness, resistance to change and self-management of learning in mobile English learning outcome. British Journal of Educational Technology, 43(6), 1004-1015. 
Hussin, S., Radzi Manap, M., Amir, Z., \& Krish, P. (2012). Mobile Learning Readiness among Malaysian Students at Higher Learning Institutes. Asian Social Science, 8(12).

Igbaria, M., Iivari, J., \& Maragahh, H. (1995). Why do individuals use computer technology? A Finnish case study. Information \& Management, 29(5), 227-238.

Igbaria, M., Pavri, F., \& Huff, S. (1989). Microcomputer applications: An empirical look at usage. Information \& Management, 16(4), 187-196.

\section{AUTHORS (2012).}

Ismail, I., Bokhare, S. F., Azizan, S. N., \& Azman, N. (2013). Teaching via Mobile Phone: a Case Study on Malaysian Teachers' Technology Acceptance and Readiness. Journal of Educators Online, 10.

Jafari, A., McGee, P., \& Carmean, C. (2006). Managing Courses Defining Learning. What Faculty, Students, and Administrators Want. EDUCAUSE Review, 41(4).

Jarvenpaa, S., \& Lang, K. (2005). Managing the Paradoxes of Mobile Technology. Information Systems Management, 22(4), 7-23.

Jung, I., Choi, S., Lim, C., \& Leem, J. (2002). Effects of Different Types of Interaction on Learning Achievement, Satisfaction and Participation in Web-Based Instruction. Innovations in Education and Teaching International, 39(2), 153-162.

Keil, M., Beranek, P., \& Konsynski, B. (1995). Usefulness and ease of use: field study evidence regarding task considerations. Decision Support Systems, 13(1), 75-91.

Kim, C., Mirusmonov, M., \& Lee, I. (2010). An empirical examination of factors influencing the intention to use mobile payment. Computers in Human Behavior, 26(3), 310-322. 
Kleinrock, L. (1996). Nomadicity: anytime, anywhere in a disconnected world. Mobile networks and applications, 1(4), 351-357.

Kline, R.B. (2011). Principles and Practice of Structural Equation Modeling (3rd Ed.). New York, NY: Guilford.

Koole, M. L. (2009). A model for framing mobile learning. Mobile learning: Transforming the delivery of education and training, 1(2), 25-47.

Leavitt, C., \& Walton, J. (1975). Development of a Scale for Innovativeness. Advances in Consumer Research, 2(1).

Lee, Y., Kozar, K. A., \& Larsen, K. R. (2003). The technology acceptance model: Past, present, and future. Communications of the Association for information systems, 12(1), 50.

Leonard-Barton, D., \& Deschamps, I. (1988). Managerial Influence in the Implementation of New Technology. Management Science, 34(10), 1252-1265. doi:10.1287/mnsc.34.10.1252

Leong, L. (2003). Theoretical models in IS research and the technology acceptance model (TAM). Technologies \& methodologies for evaluating information technology in business, 1-30.

Liu, Y., Li, H., \& Carlsson, C. (2010). Factors driving the adoption of m-learning: An empirical study. Computers \& Education, 55(3), 1211-1219.

Mallat, N., Rossi, M., Tuunainen, V., \& Öörni, A. (2006). An empirical investigation of mobile ticketing service adoption in public transportation. Personal and Ubiquitous Computing, 12(1), 57-65. 
Martins, C., Oliveira, T., \& Popovič, A. (2014). Understanding the Internet banking adoption: A unified theory of acceptance and use of technology and perceived risk application. International Journal of Information Management, 34(1), 1-13.

Mathieson, K. (1991). Predicting User Intentions: Comparing the Technology Acceptance Model with the Theory of Planned Behavior. Information Systems Research, 2(3), 173-191.

Miller, M. D., Ranier, R. K., \& Corley, J. K. (2003). Predictors of engagement and participation in an on-line course. Online Journal of Distance Learning Administration, 6(1).

Moon, J., \& Kim, Y. (2001). Extending the TAM for a World-Wide-Web context. Information \& Management, 38(4), 217-230.

Motiwalla, L. (2007). Mobile learning: A framework and evaluation. Computers \& Education, 49(3), 581-596.

Nicoll, K. (1998). "Fixing" the "Facts": flexible learning as policy invention. Higher Education Research \& Development, 17(3), 291-304.

Nunnally, J. (1978). Psychometric theory, New York: McGraw-Hill.

O’Cass, A., \& Fenech, T. (2003). Web retailing adoption: exploring the nature of internet users Web retailing behaviour. Journal of Retailing and Consumer Services, 10(2), 81-94.

Ozdamli, F., \& Cavus, N. (2011). Basic elements and characteristics of mobile learning. Procedia - Social and Behavioral Sciences, 28, 937-942.

Park, S., Nam, M., \& Cha, S. (2011). University students' behavioral intention to use mobile learning: Evaluating the technology acceptance model. British Journal of Educational Technology, 43(4), 592-605. 
Pillay, H., Irving, K., \& Tones, M. (2007). Validation of the diagnostic tool for assessing tertiary students' readiness for online learning. High Education Research \& Development, 26(2), 217-234.

Pollara, P., \& Kee Broussard, K. (2011, March). Student perceptions of mobile learning: A review of current research. In Society for Information Technology \& Teacher Education International Conference (2011, No. 1, 1643-1650).

Rogers, E.M. (1983). Diffusion of Innovations, 3rd ed., Free Press, New York, NY.

Schierz, P., Schilke, O., \& Wirtz, B. (2010). Understanding consumer acceptance of mobile payment services: An empirical analysis. Electronic Commerce Research and Applications, 9(3), 209-216.

Schillewaert, N., Ahearne, M. J., Frambach, R. T., \& Moenaert, R. K. (2005). The adoption of information technology in the sales force. Industrial Marketing Management, 34(4), 323336.

Shen, D., Laffey, J., Lin, Y., \& Huang, X. (2006). Social influence for perceived usefulness and ease of use of course delivery systems. Journal of Interactive Online Learning, 5(3), 270282.

Sheppard, B., Hartwick, J., \& Warshaw, P. (1988). The Theory of Reasoned Action: A MetaAnalysis of Past Research with Recommendations for Modifications and Future Research. Journal of Consumer Research, 15(3), 325.

Siau, K., Lim, E., \& Shen, Z. (2001). Mobile Commerce. Journal of Database Management, 12(3), 4-13. 
Spence, D., \& Usher, E. (2007). Engagement with Mathematics Courseware in Traditional and Online Remedial Learning Environments: Relationship to Self-Efficacy and Achievement. Journal of Educational Computing Research, 37(3), 267-288.

Steiger, J. (2007). Understanding the limitations of global fit assessment in structural equation modeling. Personality and Individual Differences, 42(5), 893-898.

Sternberg, J. (2012). 'It's the end of the university as we know it (and I feel fine)': the Generation Y student in higher education discourse. Higher Education Research \& Development, 31(4), 571-583.

Tan, G., Ooi, K., Leong, L., \& Lin, B. (2014). Predicting the drivers of behavioral intention to use mobile learning: A hybrid SEM-Neural Networks approach. Computers in Human Behavior, 36, 198-213.

Teddlie, C., \& Yu, F. (2007). Mixed Methods Sampling: A Typology With Examples. Journal of Mixed Methods Research, 1(1), 77-100.

Teo, T., \& Noyes, J. (2011). An assessment of the influence of perceived enjoyment and attitude on the intention to use technology among pre-service teachers: A structural equation modeling approach. Computers \& Education, 57(2), 1645-1653.

Venkatesh, V. (2000). Determinants of Perceived Ease of Use: Integrating Control, Intrinsic Motivation, and Emotion into the Technology Acceptance Model. Information Systems Research, 11(4), 342-365.

Venkatesh, V., \& Davis, F. (2000). A Theoretical Extension of the Technology Acceptance Model: Four Longitudinal Field Studies. Management Science, 46(2), 186-204. 
Venkatesh, V., Morris, M. G., Davis, G. B. \& Davis, F. D. (2003). User acceptance of information technology: Toward a unified view, MIS Quarterly, 425-478.

Vijayasarathy, L. (2004). Predicting consumer intentions to use on-line shopping: the case for an augmented technology acceptance model. Information \& Management, 41(6), 747-762. doi:10.1016/j.im.2003.08.011

Wang, Y., Wu, M., \& Wang, H. (2009). Investigating the determinants and age and gender differences in the acceptance of mobile learning. British Journal of Educational Technology, 40(1), 92-118. 